\title{
Building family business identity through transgenerational narratives
}

\author{
Maria Jose Parada \\ ESADE Business School \\ Barcelona \\ Spain \\ Alexandra Dawson \\ Concordia University \\ Montreal, QC \\ Canada
}

Final version: $\underline{\text { https://doi.org/10.1108/JOCM-10-2016-0200 }}$

Citation for published version: Maria Jose Parada, Alexandra Dawson, (2017). Building family business identity through transgenerational narratives, Journal of Organizational Change Management, 30(3), 344-356. 


\begin{abstract}
Purpose - The purpose of this paper is to understand how family businesses (FBs) build their collective identity through transgenerational narratives. The authors examine the processes through which organizational meanings are socially constructed through narratives about individuals who are closely linked to the organizations (and their family).

Design/methodology/approach - Based on qualitative research, the authors study a 180-year old Spanish Pharmaceutical FB. Using longitudinal data, the authors analyze the narratives of six family members and two non-family executives. The authors use open-ended questions to allow interviewees to elaborate their own stories, following previous studies using extended narratives that leave the stage to the narrator.

Findings - Findings based on the stories of the eight interviewees (voice) suggest that the FB identity was initiated by the founder's way to grow the business (fictionality). In turn the family shaped the identity of the FB, being reshaped by the stories arising from next generations' entry into the business (reflexivity). While the FB identity reflects that of the owners, this identity is enduring but dynamic (temporality), not only shaped by the business family behind, but also conditioned by the environment.

Originality/value - The authors contribute to the growing literature adopting a narrative method to study phenomena in FBs. Thanks to the richness of the empirical material, a narrative method is particularly suited-and novel-for understanding collective identity, a crucial organizational resource that is closely linked to leadership in the FB.

Keywords Family business, Qualitative, Identity, Narratives, Collective identity
\end{abstract}




\section{Introduction}

There has been an increasing trend to incorporate narratives in organizational studies. Narratives are stories that, in their simplest form, include a starting point, an action or event, and a consequent status; in other words, they include a 'plot', i.e. an order or logic that gives meaning (Czarniawska, 1997). In particular, narratives have been used to understand how entrepreneurial identities are created (Down \& Warren, 2008). Narratives, however, also have the power to complement and extend the understanding of collective identities, an area that has been so far underexplored (Brown, 2006). Family businesses (FBs), defined as firms where a family or families can influence the strategic-decision making with the intention to pass the business to the next generation, are a setting where collective identities are developed.

In the FB domain, narratives contribute to the understanding of processes and relations (Dawson $\&$ Hjorth, 2012). Previous studies have focused on the power of narratives as devices for value transmission (e.g. Parada \& Viladás, 2010), the relationship between family and business, highlighting the epic tragedy as a form of narrative (e.g. Hamilton, 2006a), succession processes (e.g. Dawson \& Hjorth, 2012), and the role of history in FB succession (Hjorth \& Dawson, 2016). Yet few studies focus on narratives that develop collective identities in FBs.

In our study we focus on founder and collective identities, as FBs are composed by different generations. Our aim is to explore the construction of FB identity, based on the narratives built around the founder, and next generations. Hence, we examine the processes through which organizational meanings are socially constructed (Fletcher, 2003) through narratives about individuals who are closely linked to organizations (and their family).

Our theoretical framework is based on five key elements that aid us in understanding collective identities: reflexivity (whereby collective identities are the result of a dialogue among organizational members), voice (the point of view of the actor who is telling the story), plurivocity (the different interpretations that can be given to a story), temporality (reflecting temporal experience and the way organizations evolve), and fictionality (because the stories we tell are always somehow 'edited') (Brown, 2006).

As Brown, et.al, (2006) highlight, interpretive research is a powerful method to understand how organizational identities are built. Based on qualitative research, we study a Spanish 
pharmaceutical FB founded in 1830s. Using a longitudinal case study we analyze the narratives of six family members from different generations, and two non-family executives who convey the story of previous generations, and how the stories told around the entrepreneur, his family and the coming generations have shaped and reshaped the FB identity ingrained in next generation family members as well as in non-family employees.

The paper is structured as follows. After the introduction, the paper illustrates FB identity and collective identities. Then it presents the case material in the form of narratives of different generations. It continues with discussing findings around Brown's (2006) five theoretical dimensions. Finally, conclusions are drawn.

\section{Family business identity}

FBs are organizations where a family has influence in the strategic direction of the company, and family members are involved in ownership and/or management, with the desire to pass it to the next generation (Chua et al., 1999). Identity in FBs is influenced by the presence of the founder and/or owning family, and this in turn impacts the organizations' constituents (Miller et al., 2011).

FB identity may differ if the firm is in the founder or next generation family stage (Canella, et al., 2015), as identities evolve over time and collective identities emerge. Some scholars acknowledge that identities within FBs may lead to either conflict or synergy (Sundaramurthy \& Kreiner, 2008), given the complexity embedded in two different systems, family and business.

Founders tend to maintain a strong identification with their organization (Boivie, et al., 2011), viewing the company as an extension of themselves (Wasserman, 2006), and founders' identity is "tightly linked to that of the organization and to its innovative endeavors" (Dobrev \& Barnett, 2005, p. 435). At the founder stage FBs tend to have an entrepreneurial identity and little familial identity (Miller et al., 2011). Instead, next generation family firms, having dealt with succession, intra-family conflicts, and more complex family relationships, tend to be more familial and nurturing (Miller, et al., 2011), with the company being seen as an extension of the family (Ashforth et al., 2008).

The different stages of the FB from the founder generation to the next generation show a dynamic component where collective identities take place and identities evolve. This suggests the need to understand how collective identities develop over time. 


\section{Collective identities in family businesses}

FB identity is closely connected to that of the family. The business is usually an extension of the founder/family, and therefore the difference between personal/family identity and organization identity can be fuzzy. Personal identities have to do with the self, whereas organizational identity has to do with "who we are" as an organization (Albert \& Whetten, 1985). Previous studies highlight that identities are enduring, distinctive and central (e.g. Albert \& Whetten, 1985), yet recent studies suggest that identity is more dynamic and relational (e.g., Corley \& Gioia, 2004).

Hatch and Schultz (2002), suggest that identity formation is "a dynamic set of processes by which an organization's self is continuously socially constructed from the interchange between internal and external definitions of the organization offered by all organizational stakeholders." (p. 1004) Hence, collective identity has to do with ongoing conversations, with narratives that 'bring into existence a social reality that did not exist before their utterance' (Ford \& Ford, 1995, p. 544), and these stories 'may be viewed as constitutive of organizational realities' (Boje, 1998, p. 1). Thus, identities are developed by relevant narratives (Brown, 2006) told by family members that are part of it in one way or another.

The identity of a FB may be defined as a relentless process of narrating, formulating, editing, applauding, and refusing elements of the ever-produced narrative (Czarniawska-Joerges, 1994). The essence of the FB may be 'created and re-created through the elaboration, contestation and exchange of narratives' (Brown, 2006, p. 735). Narratives that create identities in organizations are stories that individuals construct to make sense of the collective identity with which they identify (Brown, 2006). Brown (2006) suggests that identities are formed by multiple narratives, by different participants, of many different types. Collective identities, therefore, might be complicated discursive constructs with shared elements and contradictions.

Because collective identities are expressed in cultural materials, such as narratives (as well as symbols, rituals, names, and so on) (Polletta \& Jasper, 2001), narrative analysis can be a powerful methodology to investigate stories told by family members about their business. Narrative analysis differs both from ethnographic studies - which focus on the study of events rather than on the 
stories that informants create about such events - and from textual analysis - which focuses on the linguistic analysis of texts (Fairclough, 2003; Riessman, 1993). Narrative analysis focuses on the events that are told, their relationship to each other, and to the historical and relational context of such events. In this sense, individuals tell stories to make sense of their lives (or, in this case, of their family business) and through narratives identities become embedded in time and special relationships (Somers, 1994).

Key questions when working with narratives in creating identities are related to the ownership of the narrative, the motivations of the narrator, the intended audience, and the context (Brown 2006). This is particularly appealing in the FB, where reflexivity, voice, plurivocity, temporality and fictionality (Brown, 2006) can help us understand such collective identities.

\section{Research design}

The aim of this paper is to understand how FBs build their identity through transgenerational narratives. Narratives represent a form of interpretive approach, through which we can "capture the specific complexity and dynamics unique to FBs" (Nordqvist, et al., 2009, p.294), performed by different actors in multiple contexts (Dawson \& Hjorth, 2012). Flory and Iglesias (2010) highlight the important role of narratives as rhetorical devices for managers to drive organizational change.

Qualitative research requires the researcher's interpretation. The interpretive approach relies on the observer (researcher) defining and redefining the meanings of what they observe (Stake, 2010). An interpretive approach focuses on uncovering how life experiences are interpreted (subjective meaning) by individuals (Schutz, 1932/1967). Past interpretations influence present interpretations, which in turn delineate future ones (Denzin, 1984). Therefore interpretation can be seen as a temporal process.

\section{Data collection}

We used multiple sources of data: open-ended, in-depth interviews with family and non-family members, observations and secondary material. We present our data using extended narratives that leave the stage to the narrator, similar to what previous studies have done (e.g. Lindgren \& Wahlin, 2001). 
The case for this study stems from a larger project. The Successful Transgenerational Entrepreneurship Practices (STEP) Project, founded in 2005, seeks to understand how FBs transmit entrepreneurial behavior over generations. We followed this case since the beginning and built a trust relationship with the family, particularly with a key informant, who has been accessible at all times for further interviews.

Data gathered was transcribed and translated into a case study further discussed with the interviewees, allowing for interaction and enriching iterative conversations. Interviews were between 1.5 and 2 hours long. Family members from different generations, working and not working in the company, were interviewed. Interviewees had more than one role either as managers, board members, or family council members (see Table 1). The first coauthor undertook a total of 8 interviews during 2006-2008, and additional interviews were performed with the key informant in 2010-2015.

- - - Insert Table 1 about here - - -

\section{The context: LABOR Family business}

\section{The company}

The Labor FB is a privately family-owned pharmaceutical company founded in the 1830s, making it one of the oldest pharmaceutical groups in Europe. The firm has undergone many changes in relation to strategic decisions, business model, and governance structures, particularly linked to generational transitions, the complexity of the family and business, and macro conditions. After five generations of Labor family members running the business they have developed a solid company that has faced many challenges leading to important changes.

As of 2016 the business is run by an external Chief Executive Officer (CEO) supported by a solid governance structure, systems and processes to support decision making. Labor has moved from a founder-centric management style to having a top management team with four siblings and then to a single CEO.

Labor is a large company with over 700 employees; it is international and diversified, and is present in more than 150 countries. With a turnover of 150 million euros as of $2012,80 \%$ of 
revenues stem from the local and $20 \%$ from the international market. R\&D expenditure reaches $10 \%$ of total sales.

\section{The Family}

The Labor family has been actively involved in the FB for five generations. The sixth generation is in its twenties. In the genogram below (Figure 1) we observe the growing complexity of the family.

\section{- - - Insert Fig. 1 about here - - -}

\section{Identity narrative of the first generation: 1830s-1890s}

Alfred Labor started the FB in the 1830s. The Catalan tradition instilled the first born convention that children inherited the family lands. Alfred was the youngest of seven siblings, so he looked for opportunities in Barcelona.

"I think the story starts with Alfred Labor. My great-grandfather came from a village outside Barcelona because he was not the heir, looking for a job" (Alfred III)

The founder started working as an employee in a recently opened drugstore. Due to the distance to his house Mr. Labor lived in the drugstore all week, and visited his parents on Sundays.

“... he started at a very young age, cleaning floors... anecdotes from him, many! He used to sleep over the counter in summer and below it in winter...” (James II)

He was a hard worker, dedicated, efficient, and disciplined, the kind of employee the owner appreciated.

"This first generation inherited the working system of a farmer I think, because he was entrepreneurial and hardworking” (Alfred III)

“He was very entrepreneurial with lots of enthusiasm and a hard-worker". (James II)

When the owner retired, Mr. Labor bought the drugstore and started offering better quality or lower prices on the products offered (foods and remedies). Given his entrepreneurial behavior, Alfred's business expanded, as did his family. He got married and had four children. 
Alfred wanted to focus on pharmaceutical products, for which he required technical knowledge he did not possess. So he created a strategic alliance with a pharmacist. Some decades later Alfred decided to continue on his own, sowing the seeds for what is currently Labor Co.

"At that moment the merger with the pharmacist was a success because it was the key to succeed in the new area" (James II)

\section{Identity narrative of the second generation: 1890s-1950s}

Only Alfred's three boys joined the FB at a very young age, as women were excluded following the Catalan tradition. The eldest son, James, was educated to take over the reins, starting at the bottom to get to know the business from inside out. Peter and Walter were sent to school to later join their brother and support him in the business.

"A tradition of the family was that the eldest never studied. So my grandfather James was sent to do internships as apothecary. Being the son of the owner did not mean he had an easy life!" (Alfred III)

"The eldest brother was James and, as it was in that time, he did not have the option to study. He started working by taking out the rubbish. He started from below and learned the craft" (James II)

Peter took charge of the laboratory and Walter of the commercial side. Hierarchy was accepted, and it worked based on respect and authority. In the 1910s the first laboratory was created. New premises were acquired to expand the business. The business diversified by acquiring new distribution licenses and starting international sales.

\section{Identity narrative of the third generation: 1830s-1980s}

The third generation included four boys and five girls. The tradition of keeping women out of the business continued. The heir (James) had only one boy (Alfred II), assuring a shareholding dominant position. Following the family tradition, Alfred II was sent to one of the drugstores far away to start from the bottom to learn the "métier", but he also undertook business studies. Alfred II lived through the Spanish Civil War and the Second World War. This led him to running the business discretely, fearfully and with a low profile, shaping his risk-averse character. 
Alfred II's cousins, John and Steve, joined the company after completing their studies in pharmacy and sales respectively. Robert joined the company for a brief time until he died. John ran the laboratory and Steve the commercial area. Alfred II managed to handle the business through these difficult times until the next generation came on board:

"My grandfather's period was marked by the fear of war leading to a spirit of not wanting to stand out too much. Those are times that leave a mark forever. My grandfather's role, rather, was to transition, to keep the business running, which was not easy at that time, until my father was brought in." (James II)

"I heard that my grandfather was well positioned and things were running well, therefore he did not have ambition to say 'let's make the business grow '”... (Bryan)

\section{Identity narrative of the fourth generation: 1950s-2010s}

The fourth generation represented a shift in the Labor FB. The heir took an active role developing the business and delineating the long-term vision. Thirteen family members were part of this generation, five boys who joined the company and eight girls.

Alfred III joined the FB after finishing his undergraduate degree, and graduated with honors with a doctorate in pharmacy. He was the first pharmacist in the line of direct succession. His educational background was a keystone for the future development of the company.

After some years in the company he decided to launch an R\&D Laboratory. Alfred III talked about the project to his father, who was not in favor, due to his personal experience, did not see the benefits and was not familiar with it. Despite his reticence Alfred II gave his son freedom to fulfill his entrepreneurial ideas.

"It was very hard for me to convince my father how important $R \& D$ was. My father did not believe in it. For me it was different; I was very clear about it and dedicated a lot of effort to it. It was not until $R \& D$ showed positive results that he supported me" (Alfred III). 
Labor was a pioneer R\&D in the Spanish pharmaceutical industry. This strategic turn transformed the business into an important international enterprise. Alfred III was in charge of it, and Alfred II in charge of running the business.

"In the lab, my father gave me plenty of room, but where he didn't is in the administrative and commercial areas. Little by little this situation changed." (Alfred III).

Although they had been pioneers in launching an R\&D laboratory, the company did not become a large player in the industry.

"We wondered how it was possible that labs that were created much later were ahead of us: younger labs, from after the war, much more powerful. They say that as our grandfather was significantly well established, he maybe lacked enough ambition..."

(James II)

A few years later, Alfred III's second cousins, James, John, Jake and Bern joined the company. The heirs' tradition made Alfred III become the major shareholder with 51\%, maintaining a dominant position. In the 1960s the business was growing and profitable, even though the country was suffering an economic crisis. The company invested in a production plant in Latin America. Bern took over the plant in Latin America.

Running the business with several family members of two different generations became complicated, because the division of labor was blurred, and profiles and expectations were diverse. Between 1975 and 1985 the third generation of cousins, John, Steve and Alfred II, passed away.

"I haven't explained this, but I had up to eight Labor family members working in the FB with no defined functions. This situation sometimes generated confrontation among family members and confusion among lower level employees”. (Alfred III).

In the mid-1980s Alfred III wanted to continue expanding his core business. He had complemented his educational background with a business degree in a prestigious business school in Barcelona. He was also actively involved in professional associations, and networking.

Given the different vision and expectations for the future of the company, Alfred III concluded it was difficult to align positions, He made the difficult decision to buy out his second cousins' 
shares. He became the sole owner of the Labor Company in the early 1990s. The fifth generation believes that his decision determined the company's future positioning.

"My father, with initiative and determination, said "we have to move this thing forward".

This purchase represented the company's survival. Otherwise, the dynamics of many cousins working together would have been too complex to manage, eventually leading to disaster." (James II)

"I pruned the tree. I always say I have worked as a gardener pruning three branches..."

(Alfred III)

The 1990s was a decade of great expansion and diversification for Labor due to R\&D investments complemented by commercialization licenses for Spain, and the opening of an OTC (over the counter) division.

Alfred III introduced changes in management practices, but remained focused on R\&D. He was also wise, friendly and extraverted, skilled in managing relations with external stakeholders. He was President of Farmaindustria (the association of pharmaceutical firms), had close ties with the government, and was actively involved in the IEF, the Spanish FB association.

\section{Identity narrative of the fifth generation: 1980s-Current}

Six children composed the fifth generation, two girls and four boys. The tradition of excluding women from the business continued. Alfred III was not only self-demanding, but demanding of his job as well. This was a value that the people who knew him always recognized and felt.

His oldest son, Alfred IV, following his grandfather's wishes, studied pharmacy and earned his doctorate in pharmacy. He joined the company in the early 1980s, after working for some years abroad. After joining the company he moved through various areas, following the tradition of learning the business from the bottom up.

"When I was in Latin America, I worked for a small laboratory. When I joined the FB I began in $R \& D$. Then I supervised the production department. When the agreement was reached between my second cousins and my father, I took over the purchasing department..." (Alfred IV) 
The second son, Bryan, studied business administration and followed a management program in a prestigious business school. After several years working for a law firm he joined the FB.

“...I was convinced that my path was not in Labor Co. because I failed in my veterinarian studies. I remember my father was all by himself at that time and had trustworthy employees but they were not family members. He perhaps thought it could be useful to ask me about the possible purchase of two laboratories and obtain feedback from another source. Possibly his advisor told him to buy and my father said "let's see what my son says". Well, I recommended not to buy, and so he offered me a job starting as a controller in the chemical plant. In the end, I ran the chemical division." (Bryan)

The third son, Brad, also studied business and undertook a management program at the same school as his father and brothers. After graduating he joined a consulting firm developing his own path but, after some years, he was asked to join the FB.

"I planned on developing my career in the consulting firm. After three years being there, a business situation developed here. There was a vacancy; there was a problem and a series of actions had to be taken... they asked me to join.

They gave me a managerial role as head of organization and systems. Later on I assumed responsibility for some administrative and financial matters as well."

(Brad)

The youngest brother, James II joined a law firm after his studies. He did an MBA in another prestigious business school in Barcelona to reorient his professional career. He gained experience outside the FB and was then invited to join the FB.

"I worked for five years in criminal law. It turned to be stressful job, due to the cases I had to handle; distressed executives who would end up in prison. I decided to reorient my professional life and did an MBA. At that time I joined the FB... My father didn't make me join, but he encouraged me. He wanted to have all four of us here, with a sense of equality among us." (James II)

During this generation some of the old traditions were changed. In the 2000s the brothers, whilst rethinking the FB, decided that excluding women from the business was unfair. With their father 
they decided to include Tati in the FB as a shareholder, each brother ceding a proportional part of their shares to her.

"My situation is pretty different from my brothers'. I was told that I would never be a shareholder or work for the company. Once my four brothers were working for the firm, my father began to think about the next generation. I've never known whether it was my father or my brothers' doing, because my father always told me “it was your brothers'

$$
\text { generosity..." (Tati) }
$$

When the four boys joined the FB they started working in specific areas, reintroducing a clear division of labor. Alfred IV was in charge of sales and institutional relationships; Bryan joined the production plant, dealing with logistics, engineering and environmental issues; Brad took over administration and the commercial areas; and James II focused on corporate law and human resources. The siblings started working together as a team, supporting each other in the changes they needed in their respective areas.

"Alfred IV was the first to identify the need for change, but my father did not pay much attention to what he was trying to do, so he needed someone else's support. When they

hired me, he asked me to give him a hand and between the two of us we began to introduce changes in the chemical plant. This story was repeated with my other two brothers, Brad and James II. (Bryan).

\section{Discussion}

The FB is a clear example of where co-narrative identities happen, as family members are enmeshed in multiple simultaneous commitments (Brown, 2006), and roles, creating interdependencies and interconnections. New stories emerge, as new milestones are achieved by the founder and they mix with those of incoming generations. These new stories are interpreted, re-framed and re-told, generating new versions, sometimes similar, other times contradictory (Brown, 2006). In order to understand the collective identity we refer to reflexivity, voice, plurivocity, temporality, and fictionality (Brown, 2006).

\section{Reflexivity}


The Labor FB has shaped and reshaped its identity through reflexive processes undertaken by dialogue among family members throughout the generations. The self-identity of the founder has permeated the organizational identity, as is usually the case, but this identity has changed over time due to the reflexive narratives of the family members that shared the stories. For instance, the stories about each generation building on the existing business and adding something new have led to building a collective identity. The family shaped the FB identity, being reshaped by the dialogue and stories arising from next generations' entry into the business.

The business developed and diversified with each generation. The founder technically bought a drugstore (understood as a business dedicated to selling food products of all types, including pharmaceutical products), where he worked for many years. He was considered the "right-hand" of the owner who had no descendants to inherit the business. During this first developmental stage, the business was simple and the family was small. When the second generation came on board, the newcomers decided to change the focus of the business and moved to the pharmacy side, preparing and selling formulas and cures of all types. In later years the third generation joined, and witnessed the rise of the pharmaceutical industry as a global phenomenon growing exponentially after the Second World War. The company evolved from a mere distributor to a producer and/or commercializer of products for different points of sale. These products were sold in bulk format or already bottled.

The inclusion of the fourth generation represented an inflection point in the FB, in terms of decision making, professionalization of the operational area and, an important change in the business model. Alfred III, with a strong scientific orientation, invested heavily in R\&D as a mainstream area within the FB. The previous generations had already created a Laboratory, but carrying out the R\&D for his own product was Alfred III's impulse.

The business grew and expanded with the R\&D Laboratory. Growing internationally and diversifying was also an important pathway (with a production plant in Latin America, the development of molecules in Spain and licensing distribution abroad). The fourth generation was thus the inflexion point towards professionalization and the development of governance.

When the fifth generation came on board, they started driving change from inside, with the support of an advisory board created by the father. The first important change was the design of a strategic plan to create four general management positions, clearly differentiating roles and functions. The 
second strategic plan was implemented by the fourth generation with the backing of the advisory board and agreement of the father. This plan suggested drastic changes in business strategy (from developing strategic alliances to entering a new segment, and closing plants). Some of the recommendations included the separation of business units into chemical and pharmaceutical.

\section{Voice}

The Labor family has been able to develop its identity over time due to the multiple voices that included family and non-family members taking part in the FB metamorphosis over time through their points of view (Brown, 2006). Collective identities are built based on specific purposes or interests that may lead to the formation of organizational identity, yet they need to be 'legitimated in an ongoing dialogue of the people who form the organization' (Taylor, 1999, p. 324). The FB collective identity is formed around a number of common themes. In Labor they are related to the founder, traditions, entrepreneurial behavior, capacity to transform, and capacity to work as a team. While different voices are part of these collective identity narratives, they tend to be aligned. This is also evident through the board of directors' point of view when it played a critical role in advising the brothers in terms of what direction to take. It was the brothers, however, who were engaged in making the decision about a non-family vs family CEO and to whom the job would fall if it was a family member. An independent member of the board explained how the process went, and how the four brothers managed this challenging situation in relation to the further professionalization of the FB. The choice fell upon Brad and the other brothers stepped aside from operations and supported him.

\section{Plurivocity}

The Labor case does not display evidence for plurivocity, i.e. different interpretations being given to a story (Brown, 2006). In fact, despite key changes there appears to be consensus in how the stories are told. For example when the business went from having four general managers to two general managers to lead the chemical and pharmaceutical business units, a long process of conversations and consensus decision making took place leading to choosing two of the four brothers to run each business unit. Bryan took over the chemical plant and Brad took over the pharmaceutical business. The other two brothers continued in their jobs related to functional areas.

\section{Temporality}


There are several examples in the case of temporality, reflecting temporal experience and the way organizations evolve (Brown, 2006). For example, a few years after Brad and Bryan became general managers, the four brothers were ready to apply new changes to adapt to the changing environment and reinvent themselves to survive over time. At that time, Brad was managing $90 \%$ of the business and Bryan the remaining 10\%. They saw the need to move from a co-CEO to a single CEO leadership model. This was another long process of discussions and in-depth conversations in order to reflect upon who was best suited to take on the lead and take the business to the next level. The possible options included a family or a non-family member. The strategic changes the company was facing required someone with expertise and deep knowledge of the company and industry, which is why they believed that someone from the family had to take that position, and the speed of reaction was of high importance for developing the new strategy and facing the upcoming challenges. Temporality has been key to the development of a collective identity as the stories built from these processes have helped make sense of the process the family members were following as they re-constructed their collective identity.

The fifth generation in particular has been very active in changing the business model, evolving towards related diversification and particularly reinforcing OTC and generics. They also launched a spin-off of their main R\&D activities, which they eventually sold. In the last decade they have given a new direction to the company focusing mainly on OTC products. They have also introduced important changes in terms of governance and professionalization.

\section{Fictionality}

Throughout our case the only instance in which the stories that were told seemed 'edited' (Brown, 2006) was when the sister Tati was the first woman to be allowed as a shareholder and it was not clear whether this was due to the father's or brothers' 'generosity'. It is interesting to note that we saw evidence of fictionality with reference not to a business decision or change, of which several were told, but with reference to a deep seated family and societal tradition of not allowing women to be involved in the $\mathrm{FB}$, suggesting that it was easier for family members to make tough business decisions but less so when it involved cultural values.

\section{Conclusion}


Findings based on the stories of the six family members and two non-family executives suggest that the FB identity was built around the founder and the dialogue that took place among family members across generations (reflexivity). Different points of view (voice) were typically expressed and the family managed to bring them together and continue growing the business. In fact we did not find evidence of conflict among different points of view or even of different interpretations being given to the stories (plurivocity), even when tough choices had to be made about business changes (temporality). Thus what emerges is a complex collective identity that appears to be built on a 'global consensus', which is possible but is usually thought to be "fragile and generally fleeting" (Brown, 2006: p. 20). This suggests that, although collective identities are generally the result of "competing hegemonic forces", in FBs the different voices tend to converge towards an identity that is shared, central, distinctive and enduring (Brown, 2006: p. 21), rather than transitory.

This paper builds on narratives to understand how collective identities are built from individual identity construction. We contribute to the growing literature adopting a narrative method to study phenomena in FBs. Thanks to the richness of the empirical material, a narrative method is particularly suited - and novel - for understanding collective identity, a crucial organizational resource (Glynn, 2000) that is closely linked to leadership in the FB (Hamilton, 2006b). The limitations of this paper can lead to further research. The focus on a single case gives us in-depth understanding of how identities are built. Yet, the type of identity will vary in different FBs. In collectivistic vs. individualistic cultures the way in which identity is built may vary according to the narratives that are built around the business family. Focusing on various case studies may provide a wider view on narratives and their role in building FB identities. 


\section{References}

Albert, S. \& Whetten, D. A. (1985). 'Organizational identity'. In Cummings, L. L. \& Staw, B.M. (Eds), Research in Organizational Behavior, Vol. 7. Greenwich, CT: JAI Press, 263-95.

Ashforth, B. E., Harrison, S. H., \& Corley, K. G. (2008). Identification in organizations: An examination of four fundamental questions. Journal of Management, 34(3), 325-374.

Boivie, S., Lange, D., McDonald, M. L., \& Westphal, J. D. (2011). Me or we: The effects of CEO organizational identification on agency costs. Academy of Management Journal, 54(3), 551-576.

Boje, D. M. (1998). 'The postmodern turn from stories-as-objects to stories-in-context methods'. Research Methods Forum, 3, 1-8.

Brown, A. D. (2006). A Narrative Approach to Collective Identities. Journal of Management Studies, 43(4), 731-753.

Brown, A. D., Humphreys, M., \& Gurney, P. M. (2005). Narrative, identity and change: a case study of Laskarina Holidays. Journal of Organizational Change Management, 18(4), 312-326.

Cannella, A. A., Jones, C. D., \& Withers, M. C. (2015). Family-versus lone-founder-controlled public corporations: Social identity theory and boards of directors. Academy of Management Journal, 58(2), 436-459.

Chua, J. H., Chrisman, J. J., \& Sharma, P. (1999). Defining the family business by behavior. Entrepreneurship: Theory and Practice, 23(4), 19-19.

Corley, K. G., \& Gioia, D. A. (2004). Identity ambiguity and change in the wake of a corporate spin-off. Administrative Science Quarterly, 49(2), 173-208.

Czarniawska, B. (Ed.). (1997). A Narrative Approach to Organization Studies (Vol. 43). Sage Publications.

Dawson, A., \& Hjorth, D. (2012). Advancing family business research through narrative analysis. Family Business Review, 25(3), 339-355.

Dobrev, S. D., \& Barnett, W. P. (2005). Organizational roles and transition to entrepreneurship. Academy of Management Journal, 48(3), 433-449. 
Down, S., \& Warren, L. (2008). Constructing narratives of enterprise: clichés and entrepreneurial self-identity. International Journal of Entrepreneurial Behavior \& Research, 14(1), 4-23.

Fairclough, N. (2003). Analysing discourse: Textual analysis for social research. Psychology Press.

Ford, J. D. \& Ford, L. W. (1995). 'The role of conversations in producing intentional change in organizations'. Academy of Management Review, 19, 756-85.

Flory, M. \& Iglesias, O. (2010). Once upon a time, Journal of Organizational Change Management, 23(2), 113-119

Hamilton, E. (2006a). Narratives of enterprise as epic tragedy. Management Decision, 44(4), 536550.

Hamilton, E. (2006b). Whose story is it anyway? Narrative accounts of the role of women in founding and establishing family businesses. International Small Business Journal, 24(3), 253271.

Hjorth, D., \& Dawson, A. (2016). The Burden of History in the Family Business Organization. Organization Studies, 37(8), 1089-1111.

Lindgren, M., \& Wåhlin, N. (2001). Identity construction among boundary-crossing individuals. Scandinavian Journal of Management, 17(3), 357-377.

Miller, D., Breton-Miller, L., \& Lester, R. H. (2011). Family and lone founder ownership and strategic behaviour: Social context, identity, and institutional logics. Journal of Management Studies, 48(1), 1-25.

Nordqvist, M., Hall, A., \& Melin, L. (2009). Qualitative research on family businesses: The relevance and usefulness of the interpretive approach. Journal of Management and Organization, 15(3), 294.

Parada, M. J., \& Viladás, H. (2010). Narratives: a powerful device for values transmission in family businesses. Journal of Organizational Change Management, 23(2), 166-172.

Polletta, F., \& Jasper, J. M. (2001). Collective identity and social movements. Annual Review of Sociology, 27(1), 283-305.Riessman, C. K. (1993). Narrative Analysis (Vol. 30). Sage. 
Somers, M. R. (1994). The narrative constitution of identity: A relational and network approach. Theory and Society, 23(5), 605-649.

Sundaramurthy, C., \& Kreiner, G. E. (2008). Governing by managing identity boundaries: The case of family businesses. Entrepreneurship: Theory and Practice, 32(3), 415-436.

Wasserman, N. (2006). Stewards, agents, and the founder discount: Executive compensation in new ventures. Academy of Management Journal, 49(5), 960-976. 


\begin{tabular}{|l|l|}
\hline & \multicolumn{1}{|c|}{ LABOR (Pharma) } \\
\hline $\begin{array}{l}\text { Family } \\
\text { interviewees }\end{array}$ & $\begin{array}{l}4^{\text {th }} \text { Gen: } \\
1 \text { President of } \\
\text { family council } \\
5^{\text {th }} \text { Gen- } \\
1 \text { in top management, and } \\
\text { board of directors, and } \\
\text { family council } \\
3 \text { in board of directors and } \\
\text { family council } \\
1 \text { in family council }\end{array}$ \\
\hline $\begin{array}{l}\text { Members of the } \\
\text { family owning } \\
\text { shares }\end{array}$ & $\begin{array}{l}1 \text { of the } 4^{\text {th }} \text { generation } \\
5 \text { of the } 5^{\text {th }} \text { generation }\end{array}$ \\
\hline $\begin{array}{l}\text { Other non- Family } \\
\text { members } \\
\text { interviewed }\end{array}$ & 1 member of the board \\
\hline $\begin{array}{l}\text { Generations } \\
\text { overlapping }\end{array}$ & $4^{\text {th } \text { to } 5^{\text {th }}}$ \\
\hline
\end{tabular}

Table 1. Profile of Interviewees 


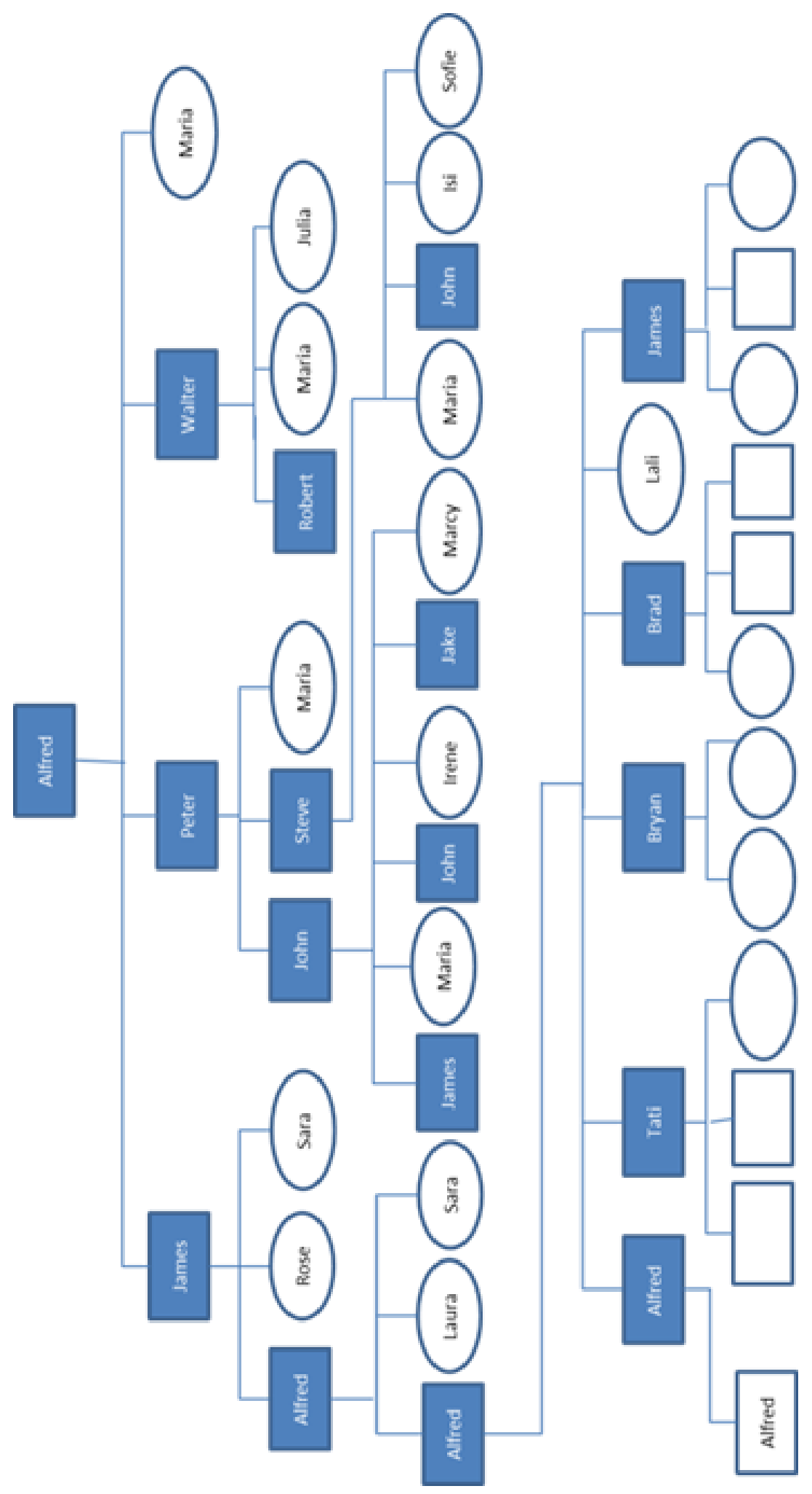

Figure 1: Labor Family Genogram 